\title{
SISTEM INFORMASI GEOGRAFIS PARIWISATA KOTA KUPANG
}

Oleh

\author{
Mailany Tumimomor ${ }^{1}$, Emanuel Jando ${ }^{2}$, Emiliana Meolbatak $^{3}$ \\ Mahasiswa Program Studi Teknik InformatikaUniversitas Katolik Widya \\ Mandira Kupang \\ Email: mailanytumimomor@gmail.com ${ }^{1}$, nuel1268@ yahoo.com², \\ emilianameol@gmail.com ${ }^{3}$
}

\begin{abstract}
ABSTRAK
Kota Kupang memiliki potensi wisata yang beragam, baik potensi alam maupun kekayaan budaya. Perkembangan pariwisata di Kota Kupang semakin meningkat, oleh sebab itu diperlukan pendekatan secara teknologi dalam mendapatkan informasi pariwisata guna meningkatkan pendapatan melalui usaha pengembangan potensi wisata daerah ini. Dengan adanya pendekatan teknologi diharapkan informasi potensi pariwisata di Kota Kupang dapat diterima dengan lebih optimal oleh para wisatawan. Kondisi ini dapat dipenuhi dengan adanya Sistem Informasi Geografis (SIG).

Metode penelitian yang dilakukan adalah dengan pengumpulan data melalui studi literature, wawancara, dan observasi, menganalisa kebutuhan perangkat lunak, melakukan digitasi peta, membangun database, merancang antar muka, dan melakukan pengujian program sebagai tahap akhir. Sistem yang dibangun berbasis web ini dikembangkan dengan menggunakan bahasa pemrograman PHP dan basis data MySQL.

Penelitian ini menghasilkan sebuah SIG di Kota Kupang yang berbasis web yang didalamnya terdapat informasi jenis wisata, lokasi wisata serta fasilitas wisata tambahan berupa informasi hotel dan travel yang ada di Kota Kupang. Sistem ini juga menyajikan informasi - informasi berita mengenai kegiatan pariwisata yang ada di wilayah Kota Kupang maupun di luar wilayah Kota Kupang yang masih tercakup dalam Provinsi Nusa Tenggara Timur.
\end{abstract}

Kata Kunci : SIG, Pariwisata, Kota Kupang, web, wisata Kota Kupang

\section{PENDAHULUAN}

Kota Kupang secara geografis disebut sebagai salah satu daerah otonom yang memiliki pesona alam maupun pesona budaya. Berbagai jenis potensi wisata seperti wisata alam, wisata kuliner, wisata budaya, maupun wisata sejarah dapat dijumpai di Kota Kupang. Potensi ini merupakan aset yang sangat bernilai untuk menarik para wisatawan asing maupun domestik untuk berkunjung dan menikmati wisata yang dimiliki oleh Kota Kupang. Namun dengan demikian pengolahan objek wisata yang ada juga harus ditingkatkan melalui kesadaran dan kepedulian 
pemerintah dan masyarakat lokal dalam memelihara objek wisata yang ada. Bantuan media penyajian informasi juga akan lebih membantu dalam memperkenalkan pariwisata yang ada di Kota Kupang.

Kemajuan teknologi di bidang komputer yang begitu pesat telah mendorong semakin berkembangnya sebuah informasi, yakni salah satunya informasigeografis dunia pariwisata. Penyajian informasi pariwisata di Kota Kupang pada saat ini masih memerlukan pengembangan dalam kegiatan mempromosikan pariwisata yang belum terkoordinasi dan penyajian informasi yang belum efisien, yakni dalam memberikan informasi mengenai lokasi atau tempat dan beberapa fasilitas wisata yang ada di wilayah Kota Kupang yang meliputi bidang wisata alam, wisata kuliner, wisata budaya maupun wisata sejarah yang memerlukan bantuan teknologi.

Untuk mengatasi permasalahan yang ada, penerapan GIS (Geographic Information System) merupakan langkah yang tepat untuk mengetahui lokasi dan informasi-informasi pariwisata yang ada di Kota Kupang, karena telah diakui GIS mempunyai kemampuan yang sangat luas, baik dalam proses pemetaan dan analisis sehingga teknologi tersebut sering dipakai dalam proses perencanaan tata ruang.

\section{DASAR TEORI}

\subsection{Gambaran Umum Kota Kupang}

Kota Kupang secara geografis terletak antara koordinat $10^{\circ} 11^{\prime} \mathrm{S} 123^{\circ} 35^{\prime} \mathrm{E}$. Kota Kupang memiliki wilayah seluas 229,97 Km2 termasuk Bandar Udara El Tari seluas 19,69 Km2. Seluruh wilayah tersebut secara administratif terbagi dalam 6 wilayah kecamatan yang meliputi 53 kelurahan

Secara topografis, Kota Kupang sebagian besar berada pada ketinggian 10$50 \mathrm{~m}$ dpl (diatas permukaan laut), sedangkan bagian utaranya (meliputi sebagian besar Kecamatan Alak dan Kelapa Lima) ketinggiannya berkisar antara 0-10 m dpl. Selain itu di Kota Kupang pun terdapat daerah-daerah yang mempunyai ketinggian > $50 \mathrm{~m}$ dpl yaitu pada bagian selatan Kecamatan Maulafa, Oebobo, dan sebagian Kecamatan Kelapa Lima yang meliputi Kelurahan Kolhua, Sikumana, Penfui, Fatubesi. Permukaan terdiri dari batu karang dan tidak rata serta tanah berwarna merah dan putih.

Iklim di Kota Kupang sama halnya dengan iklim di daerah lain dalam wilayah Kabupaten Kupang yaitu iklim kering dengan musim hujan yang pendek. Sekitar bulan Nopember sampai dengan Maret, dengan suhu udara mulai dari 200C-310C, dan musim kering sekitar bulan April sampai bulan Oktober dengan suhu udara mulai dari 29,10C-33,40C.

\subsection{Gambaran Umum Pariwisata}

Keberadaan pariwisata dalam suatu daerah biasa dikatakan merupakan suatu gejala yang kompleks di dalam masyarakat. Dalam hal ini terdapat suatu keterkaitan antara daerah objek wisata yang memiliki daya tarik masyarakat setempat dan wisatawan itu sendiri. Sejak dahulu kegiatan pariwisata sebenarnya sudah banyak dilakukan oleh masyarakat, hanya saja belum menjadi kalimat yang populer di telinga masyarakat. 
Jika ditinjau dari segi etimologis, kata pariwisata berasal dari bahasa Sansekerta yang terdiri atas dua suku kata yaitu "pari" yang berarti banyak, berkali -kali, berputar-putar, lengkap dan kata "wisata" yang berarti perjalanan atau bepergian. Dapat diambil pengertian bahwa kata pariwisata berarti suatu perjalanan yang dilakukan secara berkali-kali atau berputar-putar dari satu tempat ke tempat lain.

Seiring dengan perkembangan zaman dan pergeseran dari nilai yang terkandung di dalam kepariwisataan, maka setiap perjalanan atau kunjungan yang datang ke dalam suatu daerah tujuan wisata bisa dimanfaatkan dan dimasukkan dalam kegiatan kepariwisataan.

\subsection{Pengertian Sistem Informasi Geografis}

SIG adalah sistem berbasis komputer yang memiliki kemampuan dalam menangani data bereferensi geografi yaitu pemasukan data, manajemen data (penyimpanan dan pemanggilan kembali), memanipulasi dan analisis data, serta keluaran sebagai hasil akhir (output).

Teknologi GIS mengintegrasikan operasi pengolahan data berbasis database yang biasa digunakan saat ini, seperti pengambilan data berdasarkan kebutuhan, serta analisis statistik dengan menggunakan visualisasi yang khas serta berbagai keuntungan yang mampu ditawarkan melalui analisis geografis melalui gambargambar petanya. GIS merupakan suatu kajian ilmu dan teknologi yang relatif baru, digunakan oleh berbagai bidang disiplin ilmu, dan berkembang dengan cepat. Berdasarkan definisi yang ada, diambil sebuah definisi yang dapat mewakili GIS secara umum, yaitu sistem informasi yang digunakan untuk memasukkan, menyimpan, memanggil kembali, mengolah, menganalisa dan menghasilkan data bereferensi geografi untuk mendukung pengambilan keputusan dalam perencanaan dan pengolahan.

\subsection{Web-GIS}

Web-GIS merupakan Sistem Informasi Geografi berbasis web yang terdiri dari beberapa komponen yang saling terkait. Web-GIS merupakan gabungan antara design grafis pemetaan, peta digital dengan analisa geografis, pemrograman komputer, dan sebuah database yang saling terhubung menjadi satu bagian web design dan web pemetaan. Dimana sebuah Web-GIS yang potensial merupakan aplikasi GIS yang tidak memerlukan software GIS dan tidak tergantung pada platform ataupun sistem operasi.

\section{METODOLOGI PENELITIAN}

\subsection{Pengumpulan Data}

\subsubsection{Studi Literatur}

Mempelajari teori-teori yang berkaitan dengan penelitian yang akan dilakukan. Dalam hal ini mempelajari hal-hal yang berkaitan dengan Sistem Informasi Geografis. 


\subsubsection{Wawancara}

Melakukan wawancara dengan pihak-pihak terkait yakni Dinas Pariwisata Kota Kupang, guna mendapatkan informasi mengenai data dan lokasi tempattempat pariwisata yang ada di Kota Kupang.

\subsubsection{Observasi Lapangan}

Mendatangi langsung lokasi objek wisata untuk melihat langsung kondisi objek wisata yang sesungguhnya untuk merangkum informasi-informasi pariwisata yang nantinya akan diperlukan dalam membangun Sistem Informasi Geografis Pariwisata Kota Kupang.

\subsection{Perancangan Sistem}

Berikut Arus Diagram Pembuatan Web GIS Pariwisata Kota Kupang:

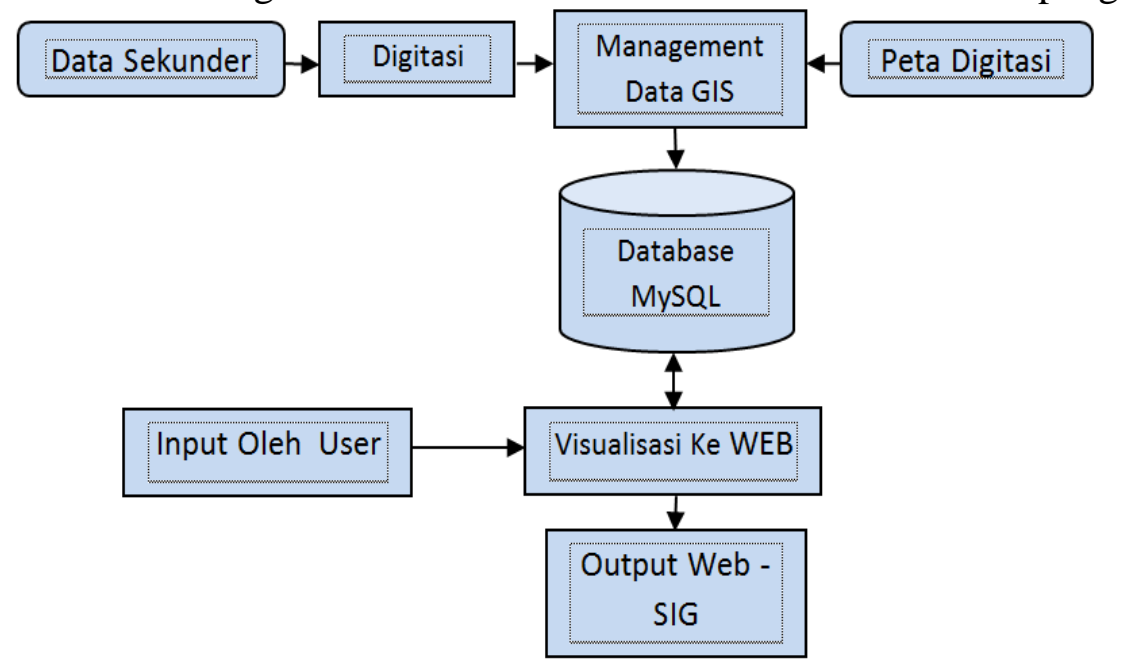

Gambar 1. Diagram Perancangan Sistem

Data yang telah di peroleh dari hasil pengumpulan data awal selanjutnya diolah untuk kebutuhan dalam membangun sistem.

Tahapan selanjutnya dalam membangun sistem ini adalah dengan merancang database, yakni dengan menggunakan database MySQL. Saat ini database MySQL telah digunakan hampir oleh semua programmer database, apalagi dalam pemrograman. Kelebihan lain dari $M y S Q L$ adalah ia menggunakan bahasa Query standar yang dimiliki $S Q L$. SQL adalah suatu bahasa permintaan yang terstruktur yang telah distandarkan untuk semua program pengakses database.

Setelah database dibangun tahapan selanjutnya adalah dengan membangun interface untuk antarmuka user. Interface yang dibangun dalam sistem ini adalah berbasis web dengan menggunakan bahasa pemrograman PHP. Perancangan interface disesuaikan dengan kebutuhan informasi yang akan ditampilkan pada website. 
Berikut ini adalah input dan output yang ada di dalam sistem yang telah dibangun:

Input :

- Data Lokasi Wisata

- $\quad$ Data Kategori Wisata

- $\quad$ Data Objek Wisata

- $\quad$ Data Fasilitas Tambahan (Hotel \& Travel)

- $\quad$ Data Galeri

- Data Berita

\section{Output:}

- Peta Kota Kupang (merupakan peta hasil digitasi yang sudah dilengkapi dengan nama Jalan serta pembagian wilayah - wilayah Kecamatan untuk mempermudah pengenalan lokasi bagi para wisatawan)

- Zoom peta Kota Kupang

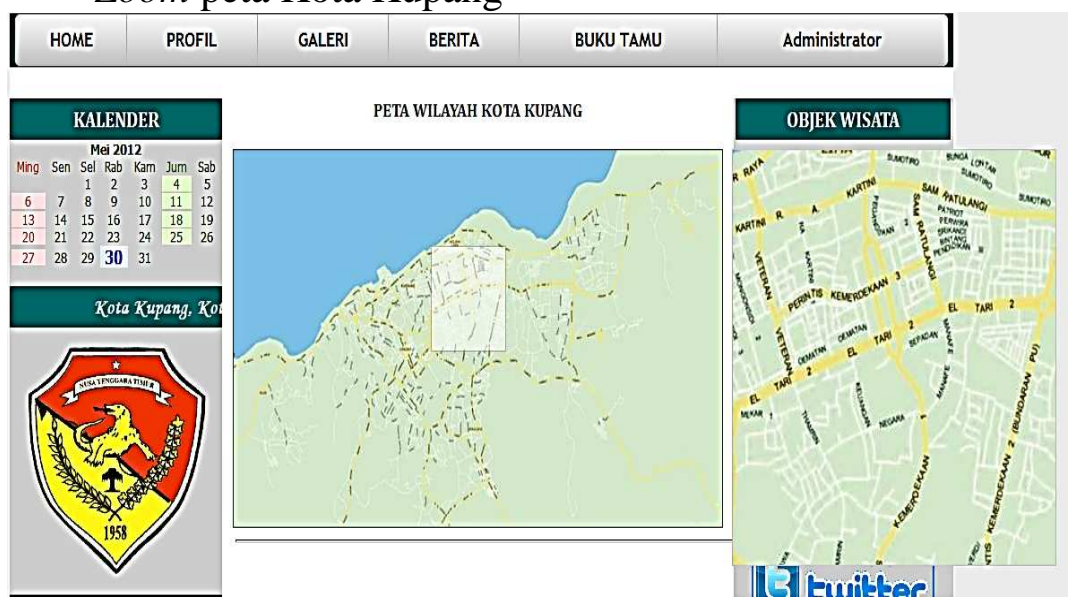

Gambar 2. Zoom Peta

- Pilihan Informasi Jenis Wisata 
ISSN 2089-8673

Jurnal Nasional Pendidikan Teknik Informatika (JANAPATI)

Volume 1, Nomor 2, Juli 2013

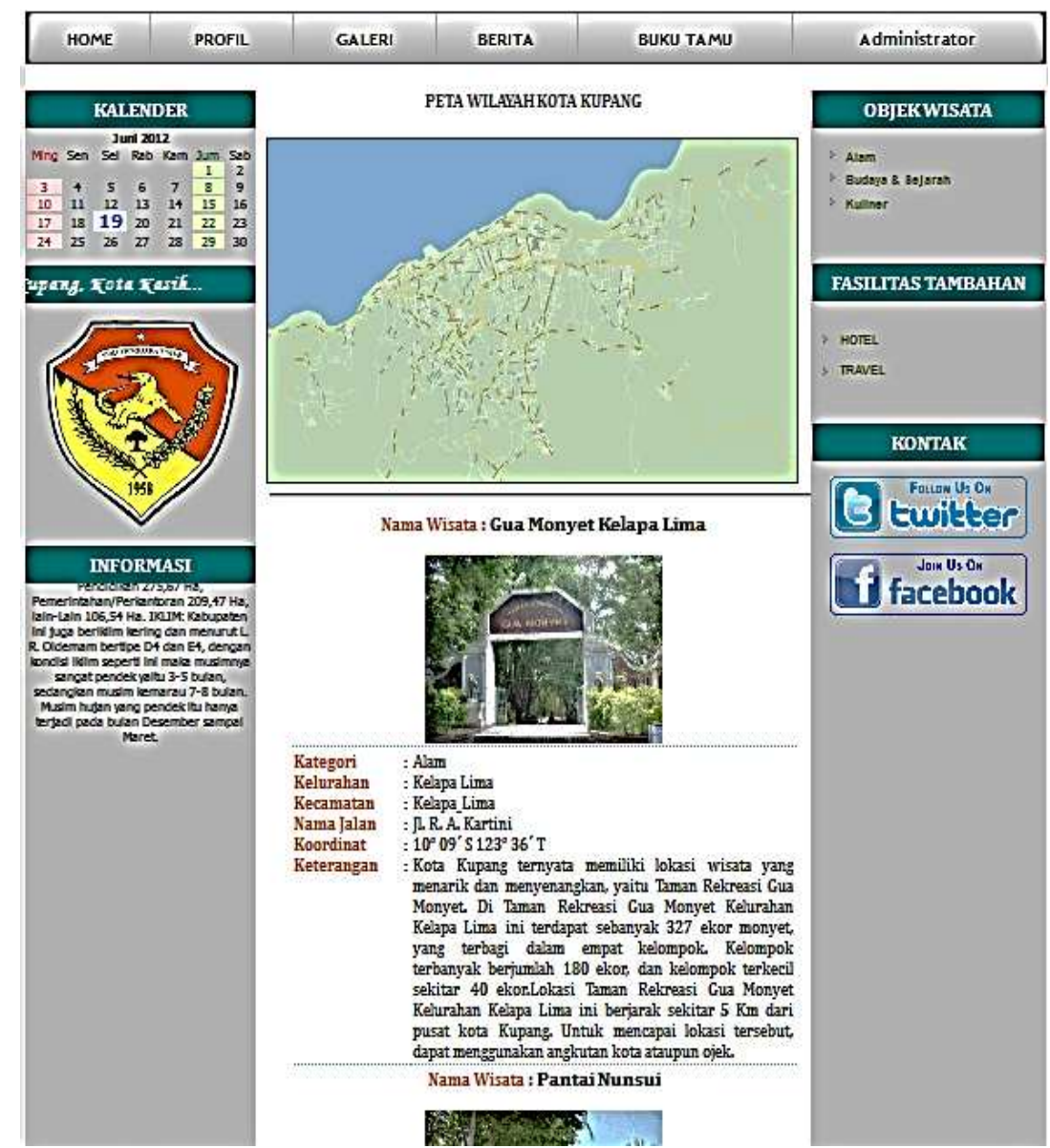

Gambar 3. Informasi Objek Wisata

Berdasarkan Pilihan Keyword 
- Galeri Foto-foto Objek Wisata

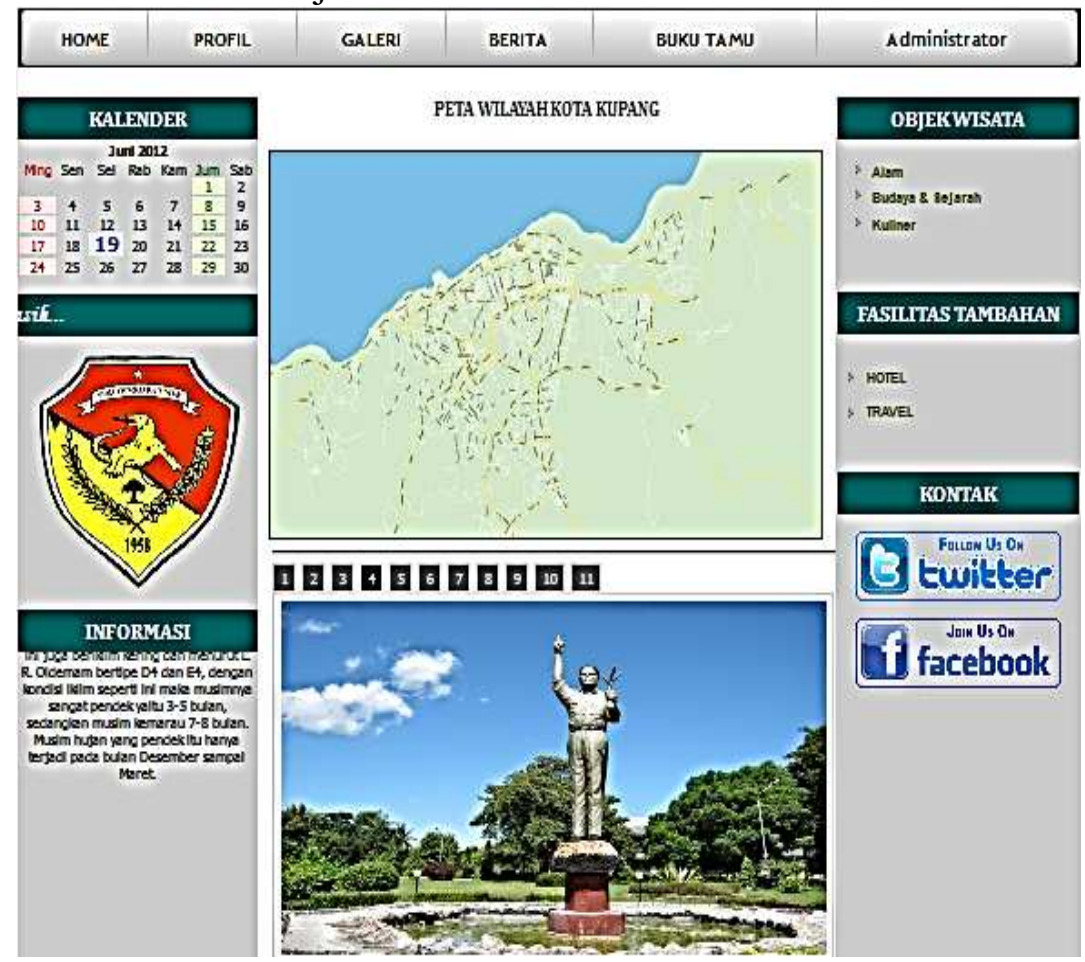

Gambar 4. Galeri Foto Objek Wisata

Kota Kupang

- Informasi Hotel \& Travel

Berisi informasi daftar-daftar lokasi dan keterangan hotel dan travel yang tersebar di Kota Kupang. 
ISSN 2089-8673

Jurnal Nasional Pendidikan Teknik Informatika (JANAPATI) Volume 1, Nomor 2, Juli 2013

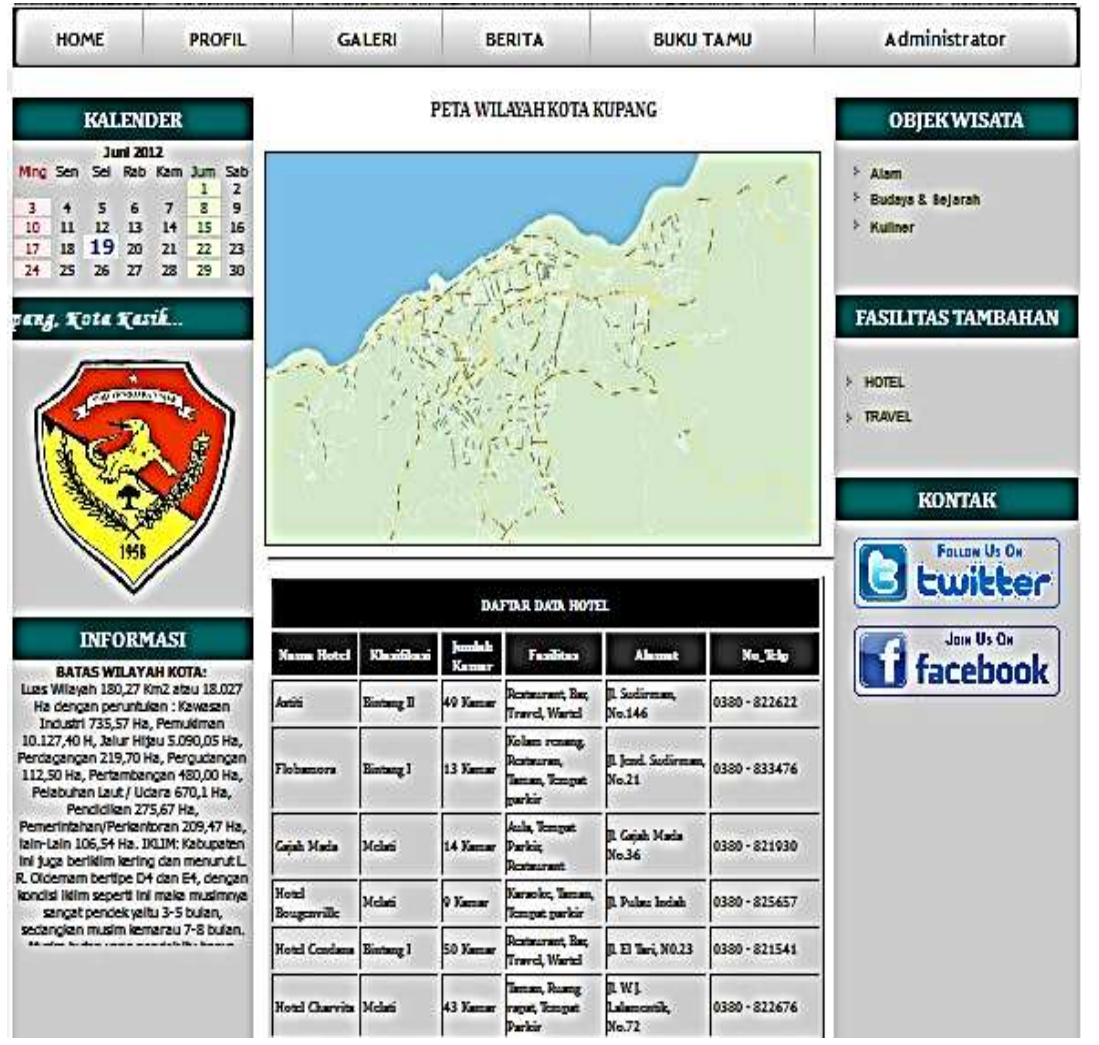

Gambar 5. Informasi Fasilitas Tambahan

\section{- Informasi Berita}

Berisi informasi-informasi kegiatan pariwisata yang pernah di adakan dan yang akan di adakah baik di Kota Kupang maupun daerah di luar Kota Kupang yang masih tercakup dalam wilayah Provinsi Nusa Tenggara Timur. 


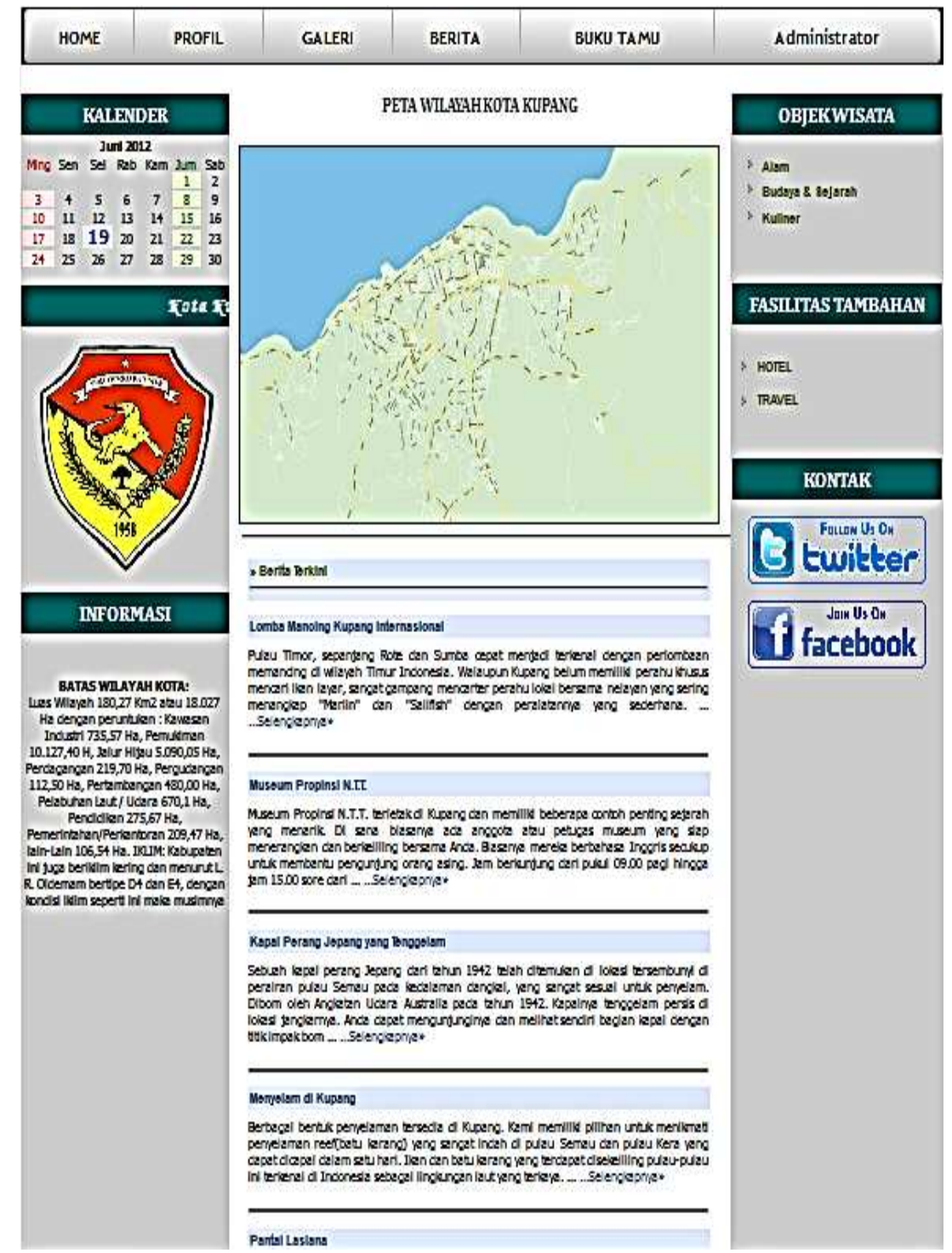

Gambar 6. Informasi Berita Mengenai

Kegiatan Pariwisata

\section{PENGUJIAN}

\subsection{Pengujian}

Metode pengujian yang digunakan dalam penelitian adalah black box testing. Pengujian black box berfokus pada persyaratan fungsional perangkat lunak. Dengan demikian pengujian black box memungkinkan perekayasa perangkat lunak mendapatkan serangkaian kondisi input yang sepenuhnya menggunakan semua persyaratan fungsional untuk semua program. Kebenaran perangkat lunak yang diuji hanya dilihat berdasarkan keluaran yang dihasilkan dari data atau kondisi masukkan yang diberikan untuk fungsi yang ada tanpa melihat bagaimnana proses untuk mendapatkan keluaran tersebut. Dari keluaran yang dihasilkan kemampuan program dalam memenuhi kebutuhan pemakai dapat diukur sekaligus dapat diketahui kesalahan - kesalahannya. 
Uji coba dengan black box pada sistem ini bertujuan untuk menentukan fungsi cara beroprasinya, apakah pemasukan data keluaran telah berjalan sebagaimana yang diharapkan. Langkah pengujian ini menggunakan dua kasus uji yaitu apabila sistem berjalan sesuai dengan harapan dan apabila terjadi kesalahan input.

\subsection{Analisis Hasil Program}

Dari hasil impementasi dan pengujian terhadap perangkat lunak, maka dapat dalakukan analisis bahwa secara umum perangkat lunak dapat berjalan dengan baik sehingga tidak menutup kemungkinan untuk dapat diterapkan pada kondisi yang sebenarnya. Pada saat admin hendak melakukan penginputan data, penghapusan data ataupun perubahan terhadap data maka admin wajib melakukan login.

Berikut adalah tabel pengujian yang dilakukan oleh admin dan user.

Tabel 1.Tabel Hasil Pengujian Sistem

\begin{tabular}{|c|c|c|c|c|}
\hline Fitur & Langkah Uji & Hasil Harapan & Hasil Tampilan & $\begin{array}{c}\text { Stat } \\
\text { us }\end{array}$ \\
\hline $\begin{array}{l}\text { Keyword } \\
\text { pencarian }\end{array}$ & $\begin{array}{l}\text { Mengklik menu } \\
\text { berdasarkan } \\
\text { pencarian }\end{array}$ & $\begin{array}{l}\text { Tampilkan sesuai } \\
\text { pilihan }\end{array}$ & (3) & $\mathrm{OK}$ \\
\hline Login Admin & $\begin{array}{l}\text { Salah memasukan } \\
\text { nama dan } \\
\text { password. }\end{array}$ & $\begin{array}{l}\text { Tampilan pesan } \\
\text { kesalahan }\end{array}$ & 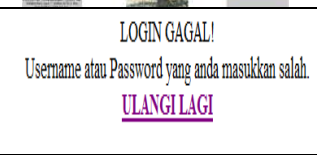 & $\mathrm{OK}$ \\
\hline $\begin{array}{l}\text { Input data pada } \\
\text { setiap form. }\end{array}$ & $\begin{array}{l}\text { Ada kolom yang } \\
\text { belum di isi. }\end{array}$ & $\begin{array}{l}\text { Tampilan pesan } \\
\text { kesalahan }\end{array}$ & $\begin{array}{c}\text { Simpan } \\
\text { Kesalahan Input: } \\
\text { 1. Data Alamat kosong } \\
\text { 2. Data Koordinat kosong }\end{array}$ & $\mathrm{OK}$ \\
\hline $\begin{array}{l}\text { Menghapus } \\
\text { data pada } \\
\text { setiap form. }\end{array}$ & $\begin{array}{l}\text { Mengklik tombol } \\
\text { hapus }\end{array}$ & $\begin{array}{l}\text { Tampilan kotak } \\
\text { konfirmasi }\end{array}$ & 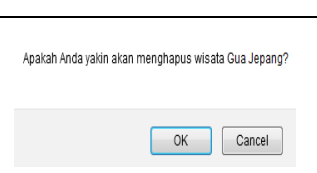 & OK \\
\hline $\begin{array}{l}\text { Mengedit data } \\
\text { pada setiap } \\
\text { form. }\end{array}$ & $\begin{array}{l}\text { Mengklik tombol } \\
\text { ubah }\end{array}$ & $\begin{array}{l}\text { Form ubah data } \\
\text { akan ditampilkan }\end{array}$ & 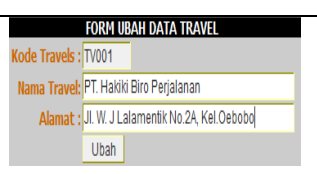 & $\mathrm{OK}$ \\
\hline
\end{tabular}

\section{KESIMPULAN DAN SARAN \\ 5.1 Kesimpulan}

Setelah seluruh sistem ini dibangun melalui tahap pengujian atau testing maka dapat disimpulkan sebagai berikut :

- Dengan dibangunnya Aplikasi Sistem Informasi Geografis Pariwisata Kota Kupang, maka sangat membantu para wisatawan dalam mendapatkan informasi mengenai pariwisata yang ada di Kota Kupang karena sistem dapat diakses langsung secara online. 
- Perancangan sistem Aplikasi ini dilengkapi dengan fungsi zoom peta, sehingga pengguna dapat mengetahui lokasi-lokasi jalan yang ada di Kota Kupang, guna mempermudah akses langsung ke lokasi objek wisata yang ingin di kunjungi.

- Target penggunaan Aplikasi ini ditunjukan untuk Dinas Pariwisata Kota Kupang, guna secara langsung meng-update data-data pariwisata yang ada di Kota Kupang, sehingga informasi yang dihasilkan lebih maksimal.

\subsection{Saran}

Saran bagi peneliti selanjutnya adalah dengan memperluas area wisata dalam hal ini bisa mencangkup keseluruhan wilayah NTT karena lokasi wilayah pariwisata di NTT saat sekarang ini cukup menarik perhatian terutama daerah flores yang menyimpan banyak pesona wisata, dan ntuk mempermudah para wisatawan dalam menjangkau lokasi wisata, dapat ditambahkan fasilitas jarak terdekat dalam menjangkau satu lokasi objek wisata ke lokasi objek wisata yang lain.

\section{DAFTAR PUSTAKA}

Perpres No. 6 Tahun 2011 / Kota Kupang

Diarta,Surya, SP, MA, 2001. Pengantar Ilmu Pariwisata. Andi Yogyakarta.

Lestari, Eny Wiji, 2011. Geografi 3 Untuk SMA/MA Kelas XII. CV Wilian

Aziz, Muhammad, 2006. Sistem Informasi Geografis Berbasis Desktop dan Web. UAD: Yogyakarta.

Susanto, Y. A. 2008. Aplikasi Sistem Informasi Geografis Berbasis Web (WebGIS)Untuk Pengembangan Sektor Industri di Kabupaten Pacitan. Retrieved Juni 2008, from yomink.files.wordpress.com/2008/03/jurnal.pdf.

Sutarman, 2003. Membangun Aplikasi dengan PHP dan MySQL. Graha Ilmu: Yogyakarta.

Agung, Gregorius, 2004. Membuat Web Blog dengan Dreamweaver \& ASP. Alex Media Komputasi: Jakarta.

http:/www.streetdirectory.co.id 